\title{
Research Article: : Social and economic empowerment of farm women in banana fibre based entrepreneurship for sustainable income
}

\author{
Veena Shahi, Brajesh Shahi, Pushpa Singh and K.M. Singh
}

Article Chronicle: Received : 01.12.2017;

Revised : 09.01.2018;

Accepted :

25.01.2018

\section{KEY WoRds:}

Banana pseudostem, Fibre extraction, Handicraft, Livelihood, Enterprise
SUMMARY : Banana is an important crop of world and India with 7.1 lakh ha area is under banana and fruit production of 26.2 million MT contributing 14.7 per cent of world production Apart from fruit, banana crop also generate huge quantity of biomass in the form of pseudostem, leaves, suckers etc. and this biomass mostly pseudostem is absolute waste in most of the states of India and Bihar in particular. Banana is cultivated in about 29 thousand ha in the Vaishali district of Bihar with an average yield of $412 \mathrm{q} / \mathrm{ha}$. With the sizable area under banana ( 0.61 lakh ha) cultivation in Bihar, it is important to develop and popularize different value added products from banana pseudostem. After harvesting of fruits and leaves, pseudostem is cut near to the ground level and its yield ranges from 60 to $80 \mathrm{t} / \mathrm{ha}$. Developing value added products from banana pseudostem is restricted mainly to fibre extraction and handicrafts making at national level. In the process of fibre extraction other components obtained simultaneously. These components are fibre (about $600 \mathrm{~kg} / \mathrm{ha}$ ), scutcher (30 to $35 \mathrm{t} / \mathrm{ha}$ ), sap (15000 to $20000 \mathrm{l} / \mathrm{ha}$ ) and central core (10 to $12 \mathrm{t} / \mathrm{ha}$ ) all of it can be used in developing different value added products. Taking the initiative Krishi Vigyan Kendra, Vaishali, Bihar started giving training to rural farm women on fibre extraction technology on the wasteful harvested pseudostem as this district is an impotant banana cultivating district. The KVK encouraged rural farm men/women to take up simple and remurative income generating enterprises from where they can earn additional income which improves its self confidence and socio- economic status having an overall impact on farm families.

How to cite this article : Shahi, Veena, Shahi, Brajesh, Singh, Pushpa and Singh, K.M. (2018). Social and economic empowerment of farm women in banana fibre based entrepreneurship for sustainable income. Agric. Update, 13(1): 101-105; DOI : 10.15740/HAS/AU/13.1/101-105.
Author for correspondence :

\section{Veena Shahi}

Krishi Vigyan Kendra,

Dr. Rajendra Prasad

Central Agricultural

University, Pusa,

Samastipur (Bihar) India

Email:veenashahi07@

gmail.com

See end of the article for

authors' affiliations 